\title{
تأخر سن الزواج وعلاقته بكل من قلق المستقبل والرضا عن الحياة لدى الأطفال
}

\author{
إعراد \\ الباحثة/ دعائ الشربيني طه علي جلال \\ باحثت ماجستير قسم علم النفسـ كليتت الآداب - جامعت المنصورة
}

اشراف

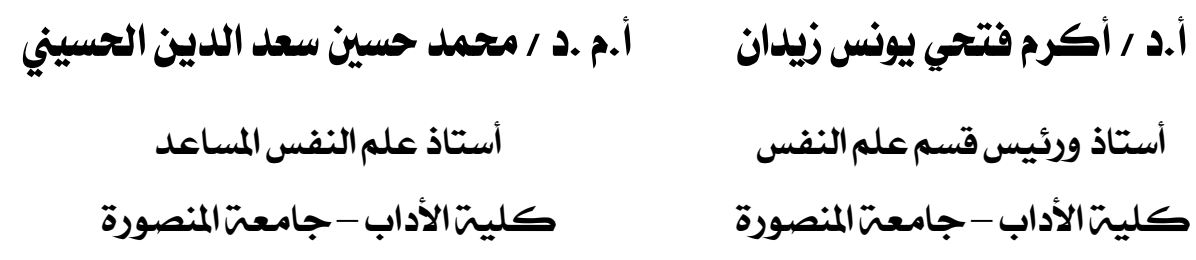

المجلت العلميت لكليتت رياض الأطفال - جامعت المنصورة

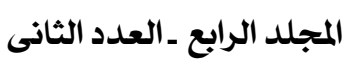

اكتوبر r. r r 


\section{تأخر سن الزواج وعلاقته بكل من قلق المستقبل والرضا عن الحياة لدى الأطفال}

\section{دعاء الشربيني طه علي جلال}

أصبحت ظاهرة تأخر سن الزو اج عند الفتيات في مجتمعاتتا العربية تُشكل

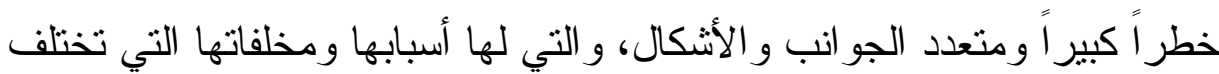

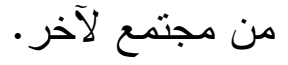

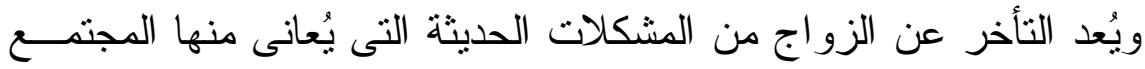


الإحصائية و المؤشر ات الخاصة بها بتتامى هذه المشكلة ، فقى العهــود الــسابقة

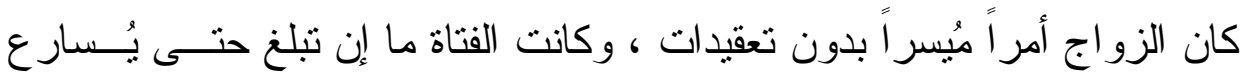

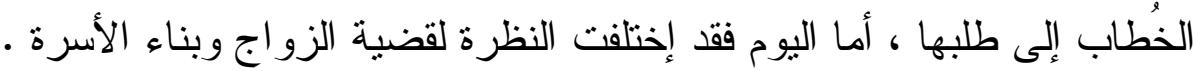
فهذه الظاهرة وقلق المستقبل تتعكس سلباً على المتأخر ات فى سن الزواج

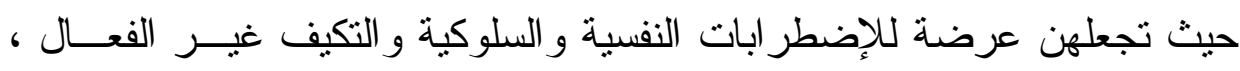

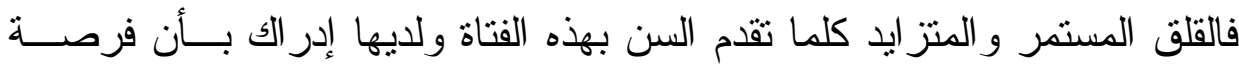

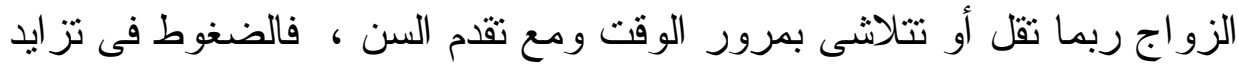

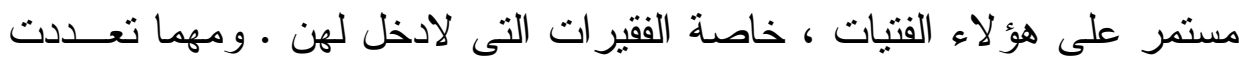

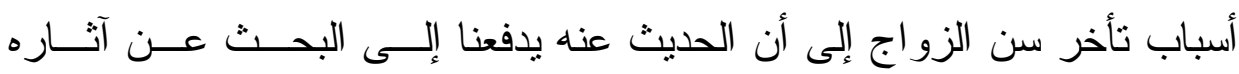

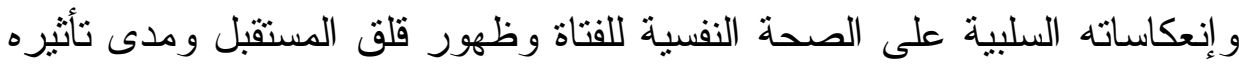
على رضاها عن حياتها.

$$
\text { * باحثة ماجستير قسم علم النفسـ كليتة الآداب - جامعت المنصورة }
$$


تأخر سن الزو اج : يُقصد بتأخر سن الزو اج هو تجاوز الفتاة سن الــزواج

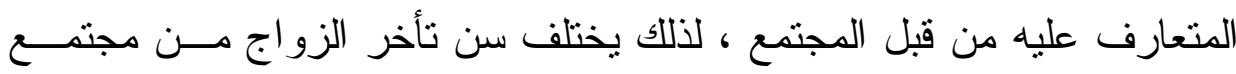

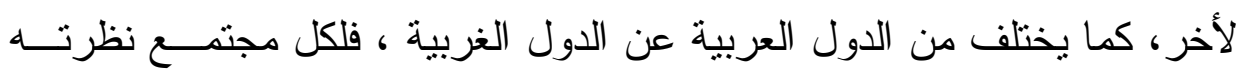

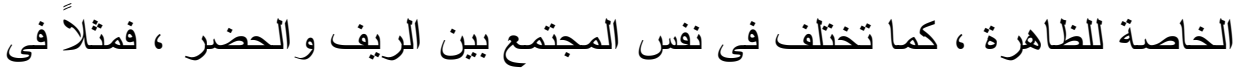

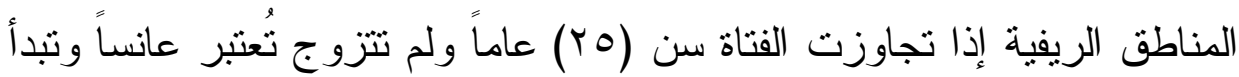

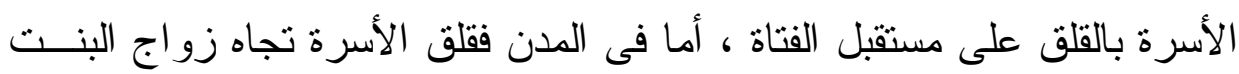



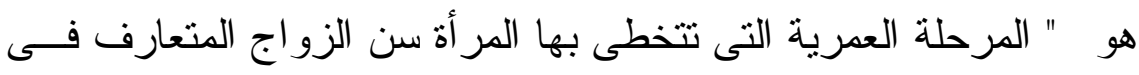

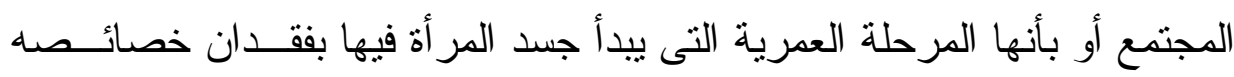

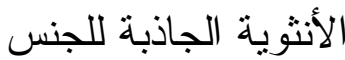
تحديد سن الزواج :

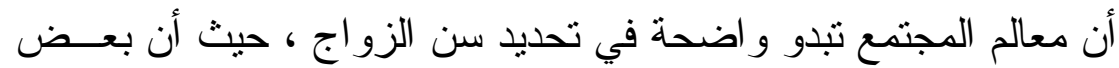

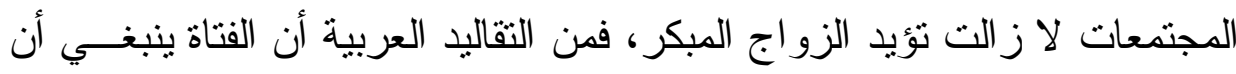

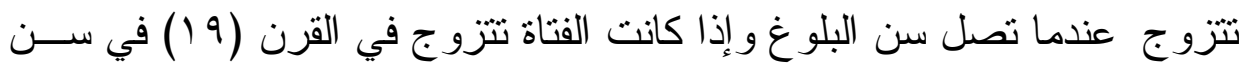

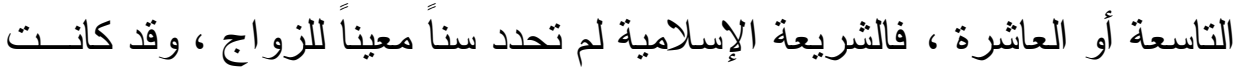

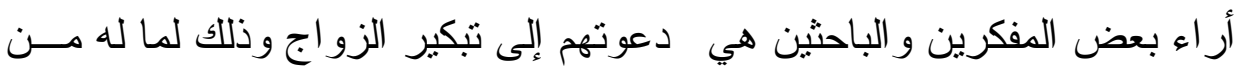

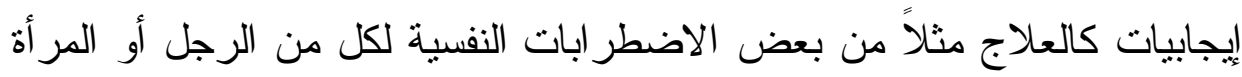

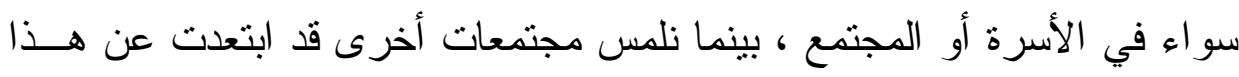

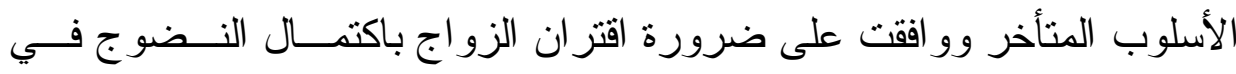

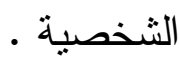

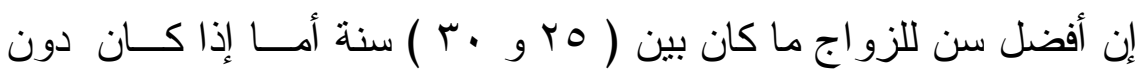

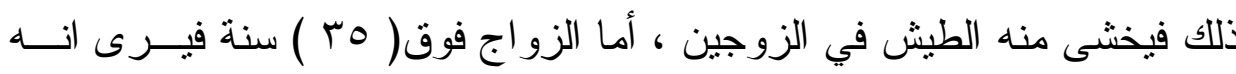




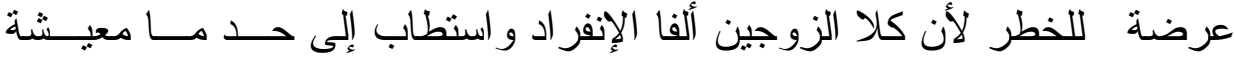



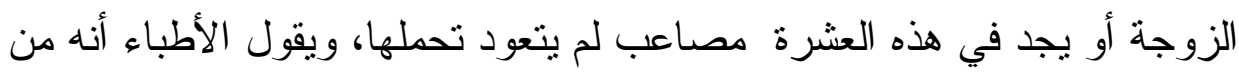

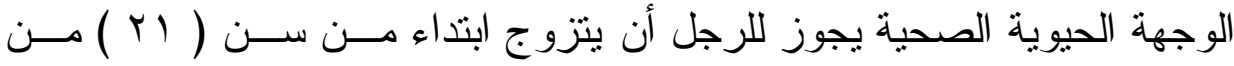

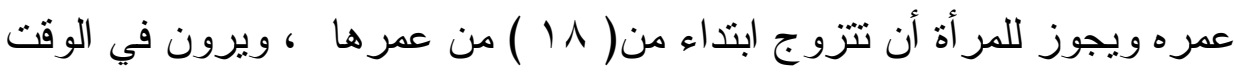

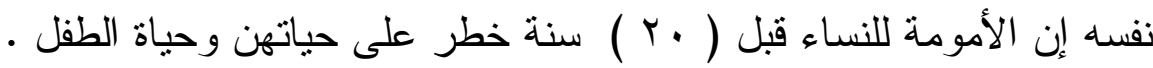
أسباب تأخر سن الزواج :

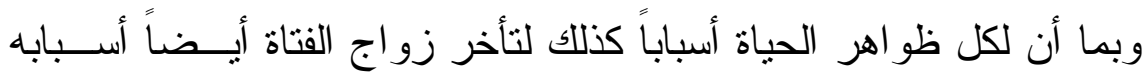

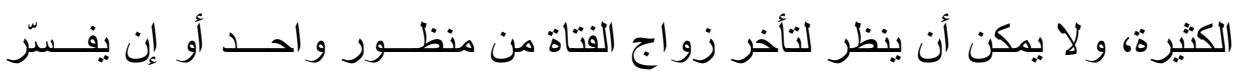

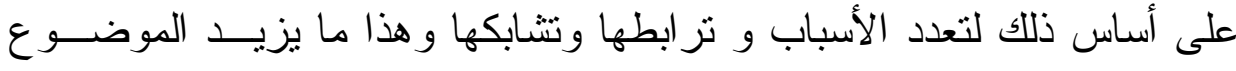

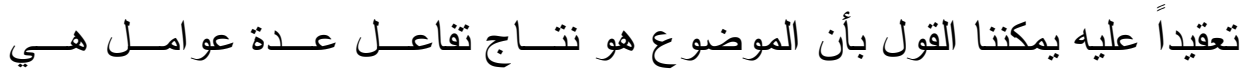





مشكلات إختيار شريك الحياة :

حياتتا فى الأساس تقوم على الاختيار ات، و أههها اختبار شــريك الحيــاة

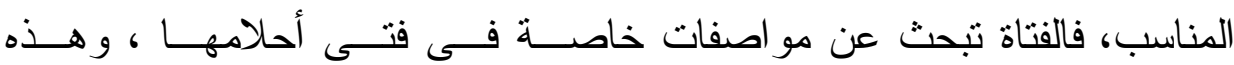
المو اصفات لاتتوفر وخاصة إذا كانت خيالية ، بل يعتقد البعض أن تأجيل قـــــار

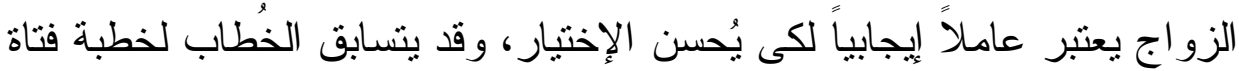

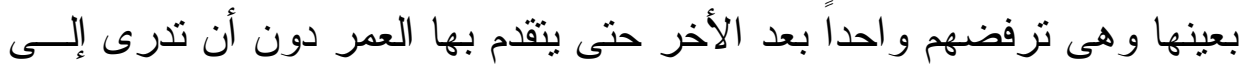



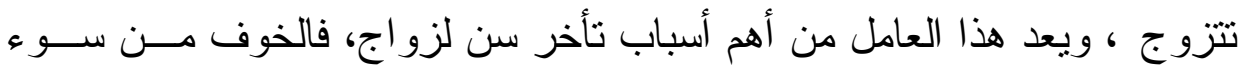

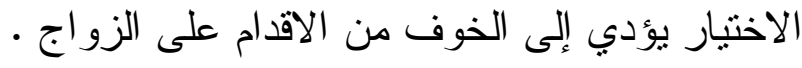


توجد بعض الثخصيات التي نزفض الزواج بوعي أو بغير وعــي علـى

الرغم مما تتمتع به من الجمال و الجاذبية، وعلى الرغم من نو افر فرص الزو اج أكثر من مرة، فالفتاة في هذه الحالة ترفض لأسباب ظاهرية كل مــن يتقــدمون

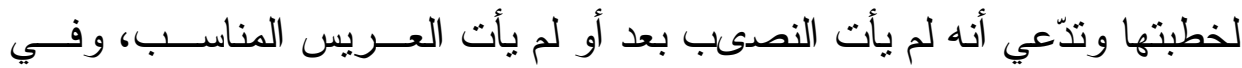
الحقيقة هي لدىها أسبابها النفسىة التي ربما تعلمها أو لا تعلمها، وهذه الأسباب

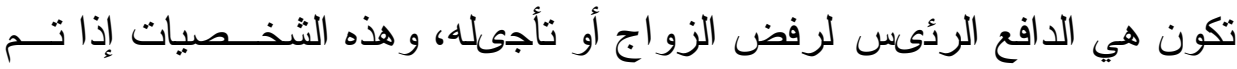
زو اجها بضغط من الأسرة أو من المجتمع فإنها سرعان ما تسعى نحو الانفصال

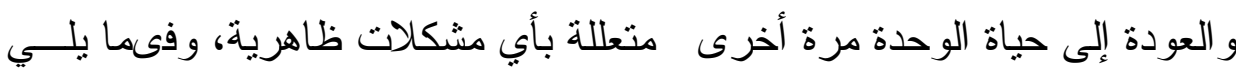
نستعرض بعض النماذج من هذه الثخصيات : الثخصية الههيستيرية:

و هي في الغالب فتاة جميلة وجذابة و استعر اضية ومغوية، توقع في حبها الكثيرين وتبدي في الظاهر مشاعر حارة، ولكنها لا تستطيع أن تحب أحدا، بل هي دائما تحب حالة الحب ذاتها، وهي سريعة الملل؛ لذلك تتنقل من علاقة إلي أخري بحثا عن الإثارة و التجديد، وعلي الرغم من إغو ائها الظاهر فإنها تعاني برودا جنسيا، ولذلك لا نز غب في الزواج لأنها تكره العلاقة الجنسية وتخشاها، إعاه و اذا حدث وتمت خطبتها فإنها تسارع إلي محاولة إفنال الخطبة، وتتعدد

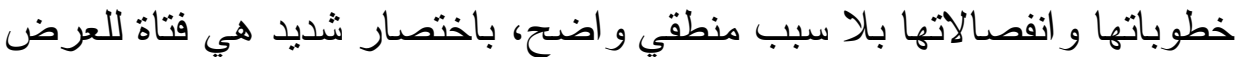
فقط، ولذلك يكثر وجودها في الأنشطة الاستعر اضية كأعمال السكرتارية و الرقص و التمثيل. 
إضطراب الثخصية المنرددة أو الوسواسية يجعل الفتاة دائمة التردد

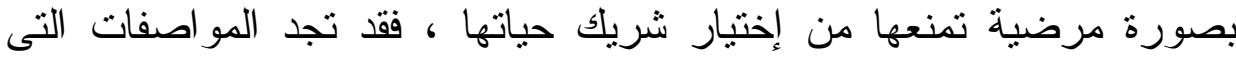

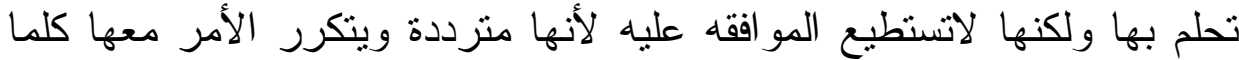
تقدم لها شخص مناسب. وهى مرنبة ومنظمة جداً بخيلة فى مشاعر ها و لاتتحمل أخطاء الطرف الآخر وترى العلاقات الجنسية شيئًا مقززاً.

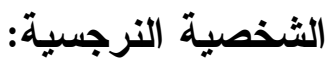

وهي الفتاة المتمركزة حول ذاتها والعاثقة لنفسها، والتي تزى أنها

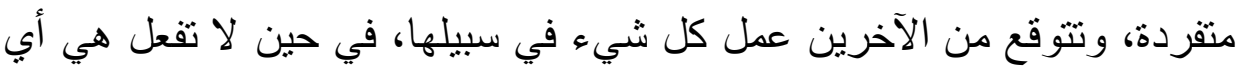
شيء، وهي تستغل كل من حولها لصالحها دون أن تعطيهم شيئا، إضافة إلى لى أنها غير قادرة على حب أحد فهي لا تحب إلا نفسها.



وهى شخصية لا ترضى الا بالكمال التنام وهى شخصية قلقة وتبحث عن

المثالية و لا يعجبها فى الرجل الا العقل .

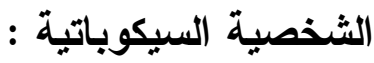

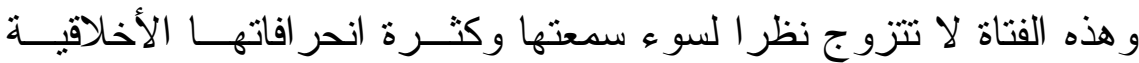

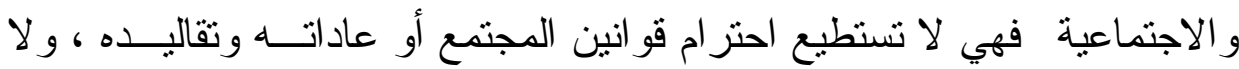
تلتزم بالمبادئ الأخلاقية المتعارف عليها، وتعيش باحثة عن اللذة الثخصية دون

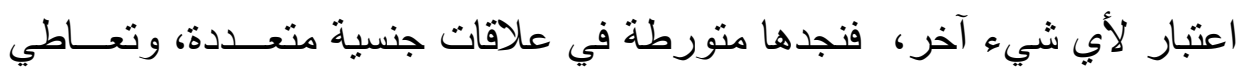

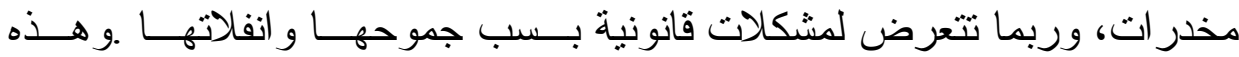

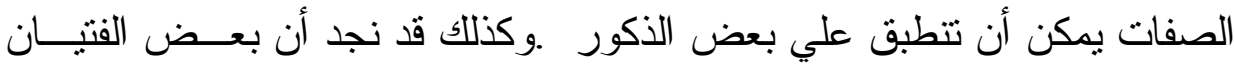

المجلد الرابع




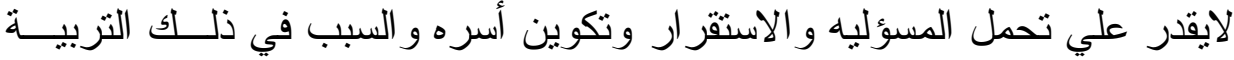

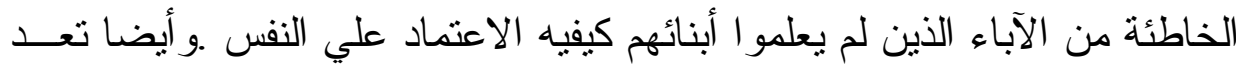

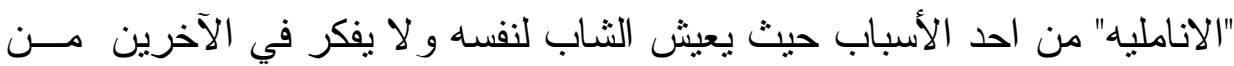

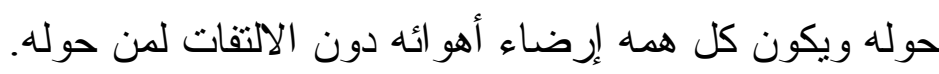



ويغلب عليها الثكك في كل من حولها، فهي لا تثق بأحد أبدا سواء أكان

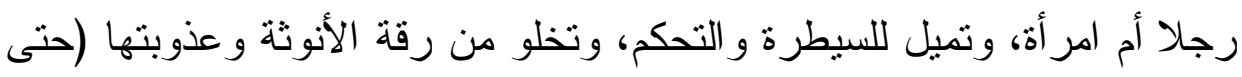

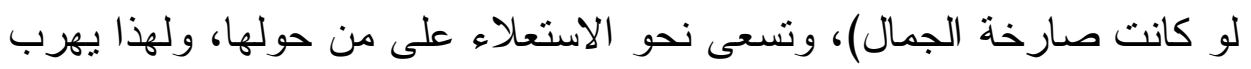

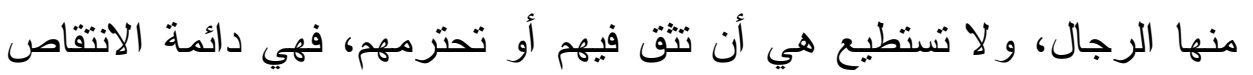

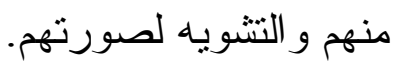

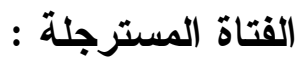

وهي قد تأخذ المظهر الذكوري في بعـض صــفاتها أو طريقــة لبـسها

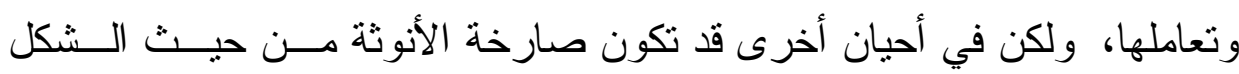

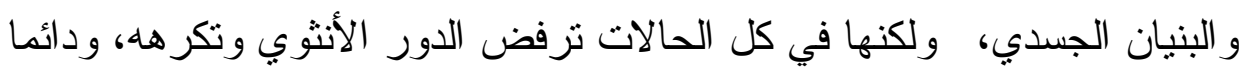

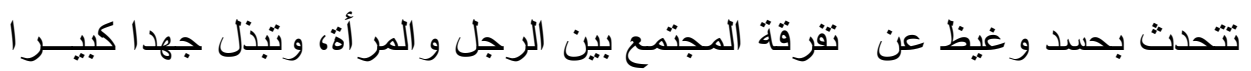

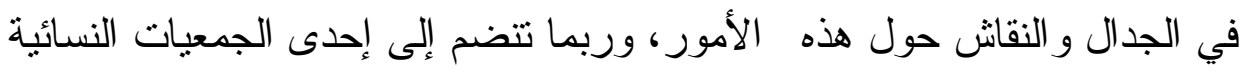

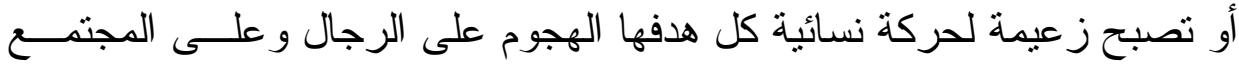

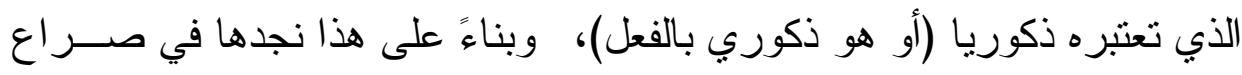

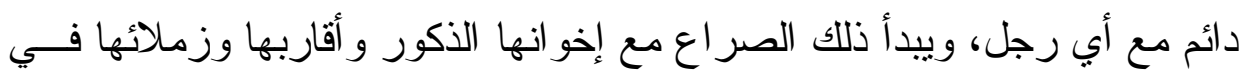

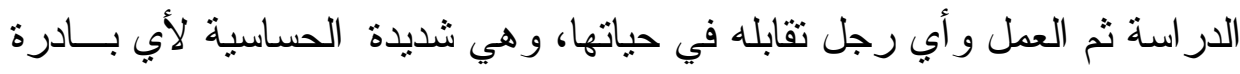

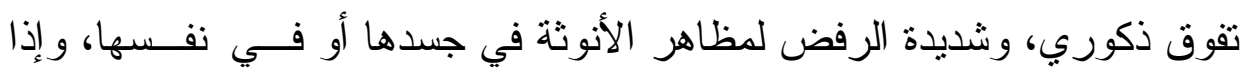

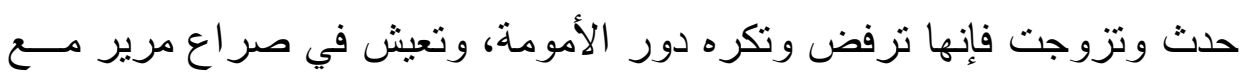


زوجها حتى تصل إلى الطلاق أو إلى التحكم فيه لترضي ميولها "الاسترجالية " الكامنة أو الظاهرة.

\section{الثخصية الإطوائية :}

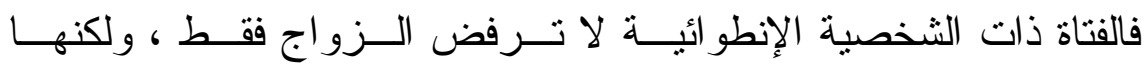

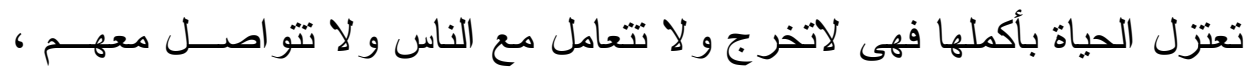

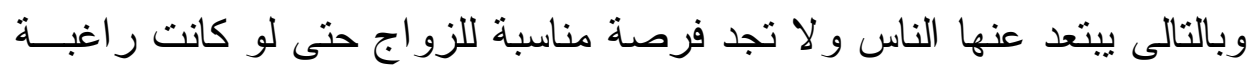

الثخصية الإففعالية :

وهى الثخصية العصبية المبالغة فى ردود فعلها ؛ فتصرفاتها تُعد عنها

الطرف الآخر ؛ وتُعرض تجاربها جميعاً للفنشل.



حيث تتقص الفتاة شخصية أمها وتتفاعل مع هذا التقصص تقاعلاً يــؤدي

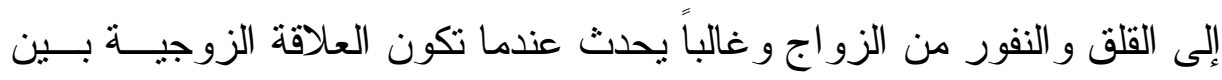
و الديها سيئة. عدم الثقة فى النفس :

فالفتاة يكون لايها فكرة خاطئة تماماً عن نفسها تؤدى إلى تأخر سن

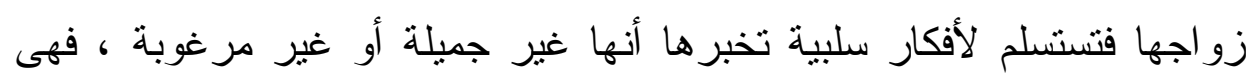
فى حاجة إلى البحث عن نقاط القوة و التميز بداخلها و عدم إنتظار عاملاً خارجياً لكسب الثقة بالنفس. 


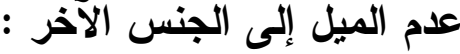

و هو إضطر اب نفسي نادر ولكنه موجود ويعالج بالجلسات النفسية .



بعض الفنتات تعانى من مخاوف مرضية تمنعها من الزواج متعلقة بعلاقتها بالجنس الآخر ، فهى لا تدرك أسباب هذا الخوف الحقيقى و التى هنى تكون كامنة فى عقلها الباطن وقد تخضع للعلاج النفسي و لا يتم إكتشاف السبب إلا بعد عدة جلسات ، فالخلافات الأسرية في الصغر يقوم عقل الطفل بتخزينها بصورة سلبية وتكون هذه الخلافات مصدر تشوه وخوف داخلي في نفوسهم، عندما يكبر الطفل ويتذكر هذه الخلافات التي عاثها بالفعل، يتم تحول فكرة الزواج في عقله إلى فكرة ساذجة وفاثلة، ويخاف من أن ما حدث بين و الديه يحدث معه هو أيضًا، ليتكون حاجز داخلي مستتر داخله تجاه فكرة الزواج.

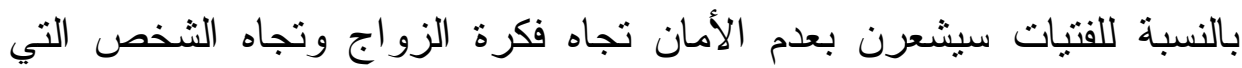

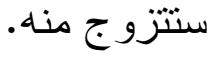

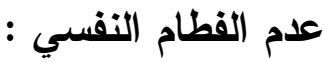

ويقصد به التعلق المرضى بالأهل أو قلق الإنفصال وهو مـن الأسـباب

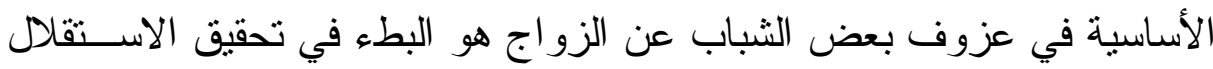

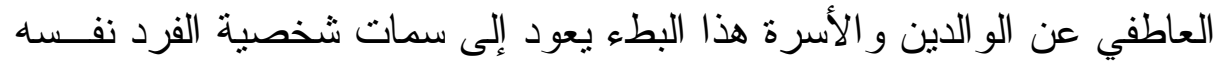

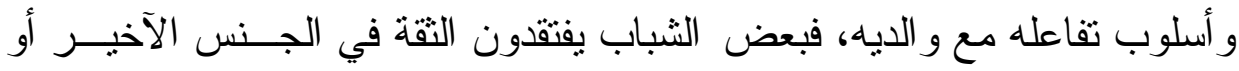

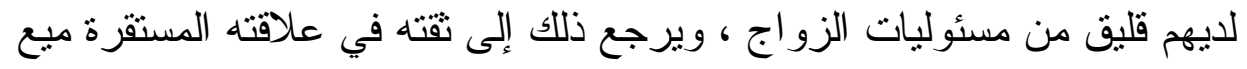
أسرته وو الديه ويكتفي بهيذه العلاقة و لا ير غب في إقامة علاقة صحيحة خـارج نطاق الأسرة و لا يقبل أب إبدال لهذه العلاقة. 
الأفكار اللاعقلانية والوساوس التي تراود الفتاة:

مثل الخوف من الفثل في الزواج أو النتشاؤم من الرجال وأن فيهم القسوة

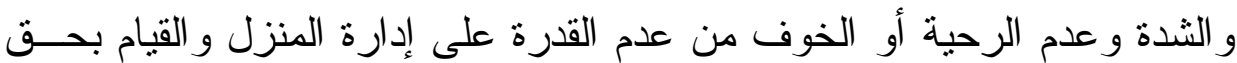

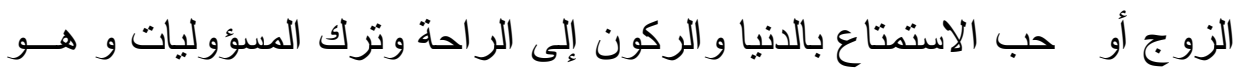

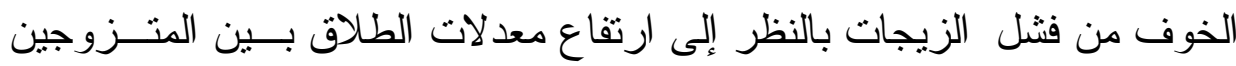

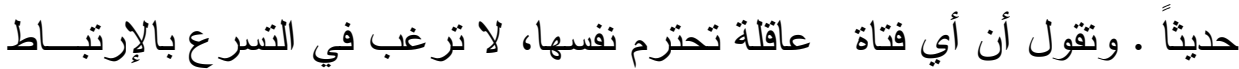

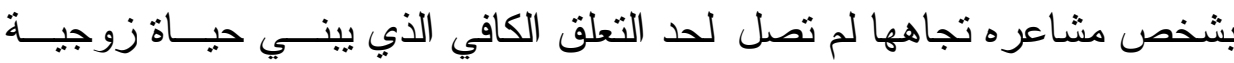

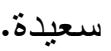

إهتزاز صفات الرجولة والأنوثة: - إن

فقد تميعت صفات الرجولة لدى الذكور مما جعل كثيرً أ من الفتيات ينظرن

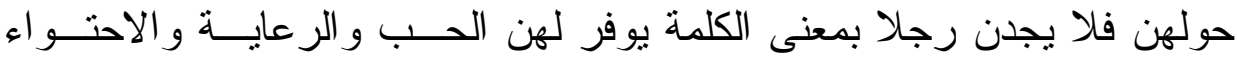





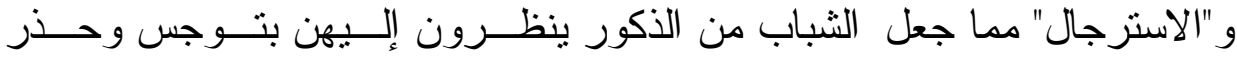

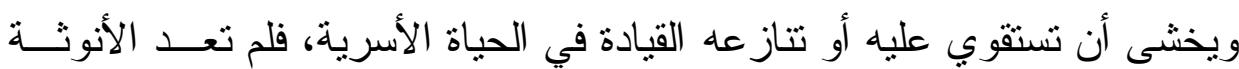

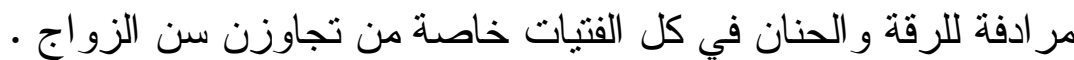

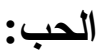

قد يكون الحب سبب في تأخر سن الزو اج فمثلا شـاب يحـب فتــاة حبــاً

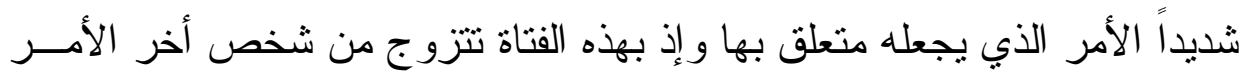

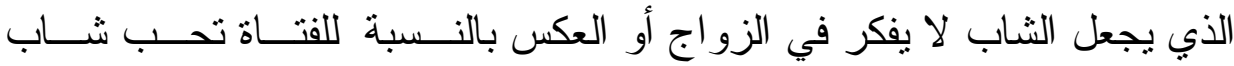

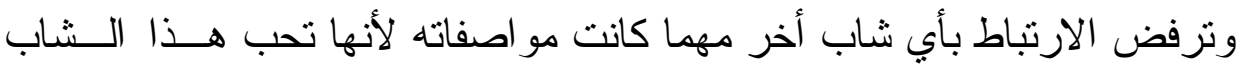


الذي قد يتركها في أي وقت من الأوقات فإذا بها تجد نفسها وقد فاتهــا قطــار

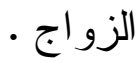

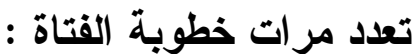

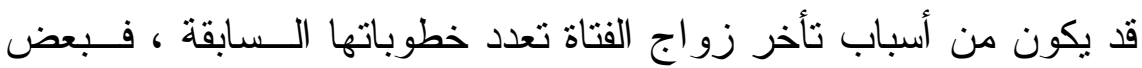

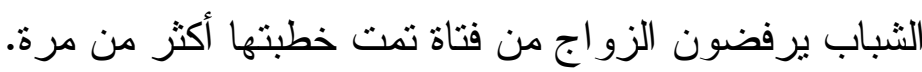
إصابة الفتاة بعاهه أو إعاقة :

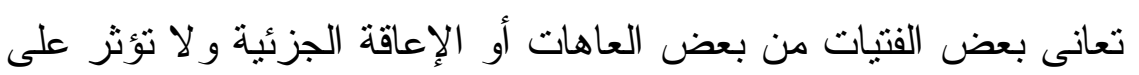
قو اها العقلية أو النفسية وتستطيع ممارسة حياتها العادية ، ولكن البعض يرى أن الفتاة المعاقة لا تمكنها حالتها من الزو اج و الإنجاب وتحمل المسئولية. التاريخ السيبء لبعض أفراد الأسرة : ير غب بعض الثباب فى الإرتباط بفتاة لكن الأهل يرفضون بسبب ســعة

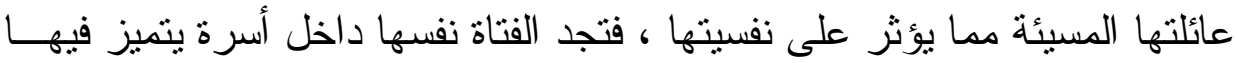

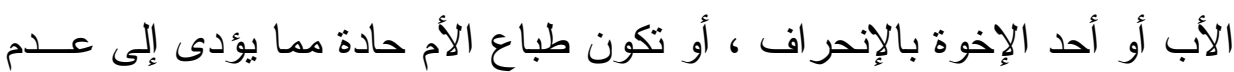

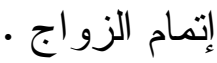

الآثار النفسية لتأخر سن الزواج : الن

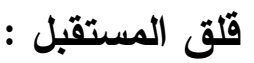

فالفتاة التى تأخر بها سن الزواج يحدث لايها قلق المستقبل خـشية عــدم

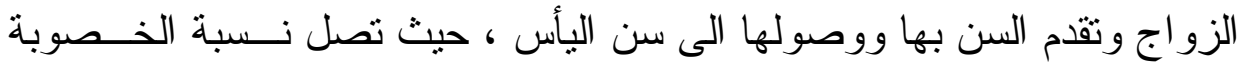

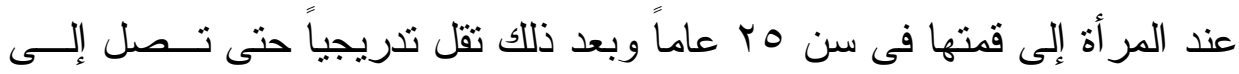

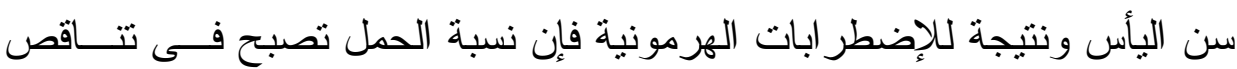

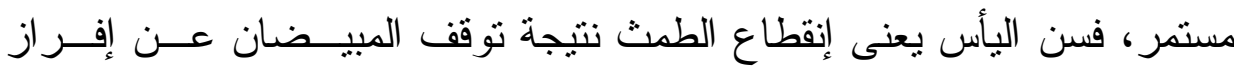


الهرمونات الأنثوية و إرتفاع مستوى هرمون الجونادوتروفين ، وبذلك تزيد نسبة

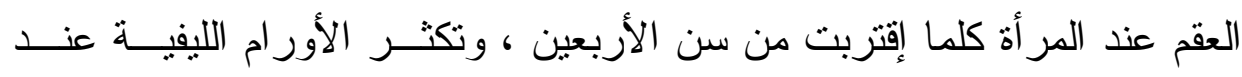



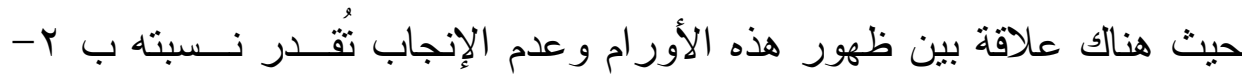

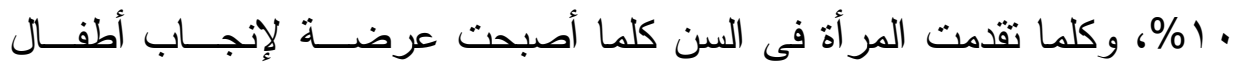
منغولين بنسبة أكبر.

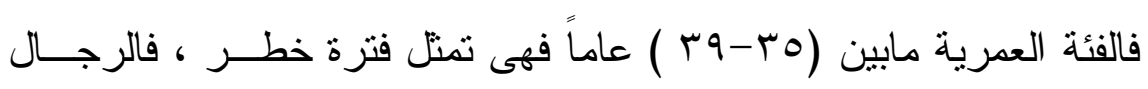

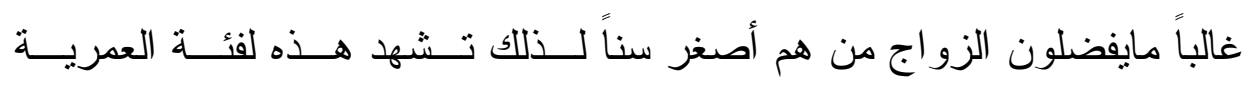

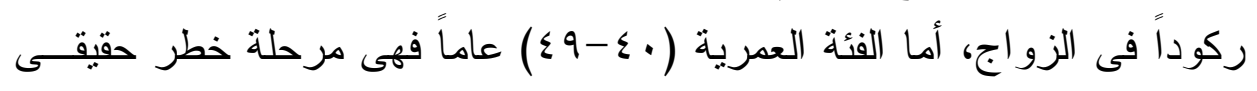

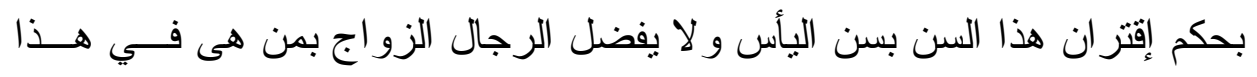
السن .

تشعر الفتاة التى تأخر بها سن الزواج بأنها عبئًا تقيلاً على أسرتها خاصة

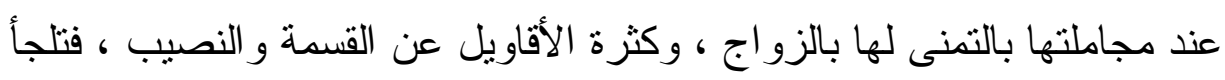

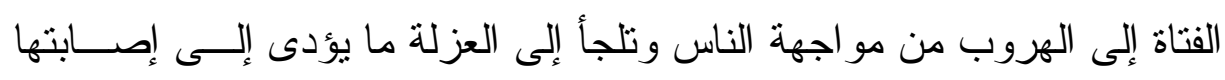

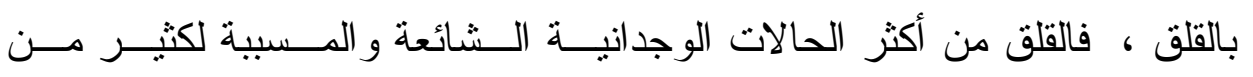

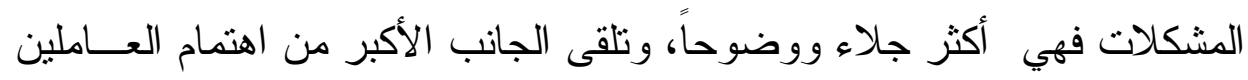

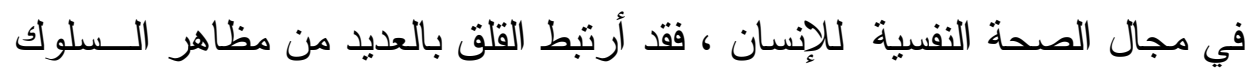

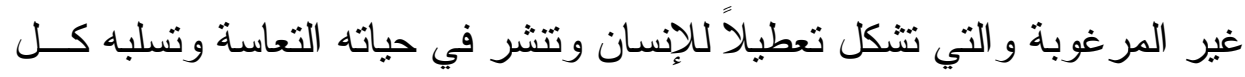
· مظاهر السعادة الإكتئاب:



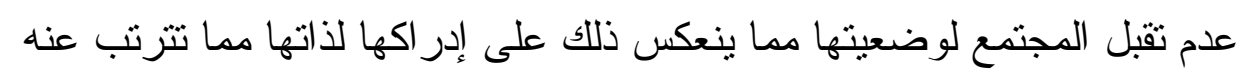




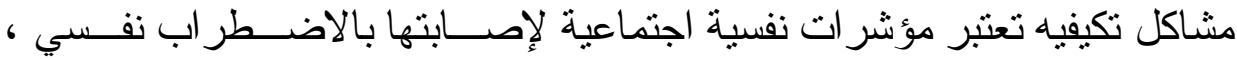

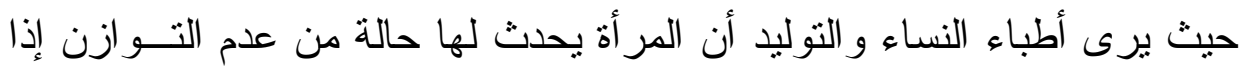

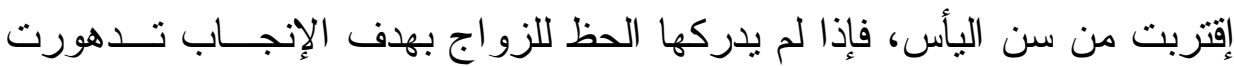

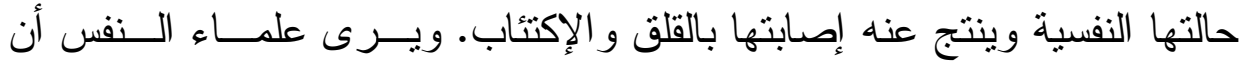

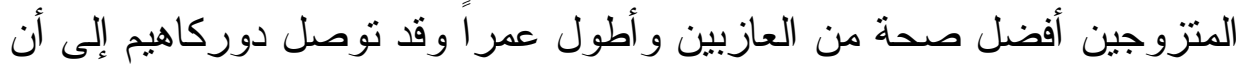

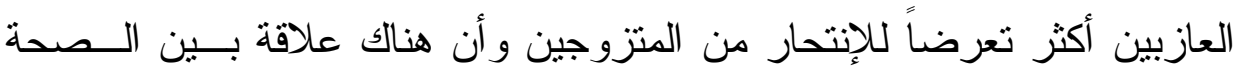

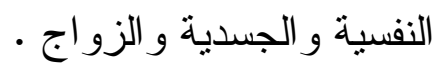

الوحدة النفسية و العزلة الإجتماعية :

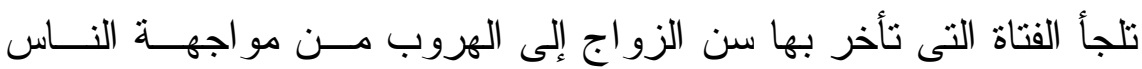

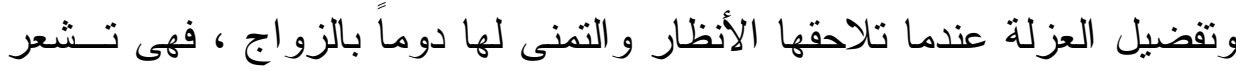

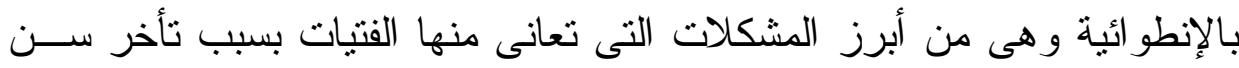
الزو اج.

فهناك نوعين من الوحدة النفسية : الوحدة النفسية العاطفية : وهى شــكل

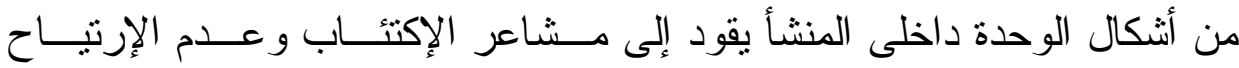

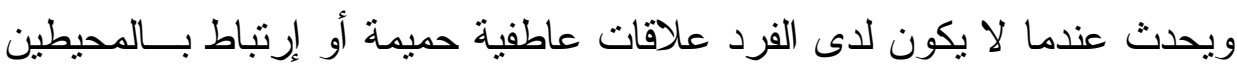
به و الثخص الوحيد عاطفياً يفتقد روح الود و التفاهم و الحــب فــى علاقاتــهـ ، الوحدة النفسية الإجتماعية : وهى شكل من أثنكال الوحدة النفسية خارجى المنشأ

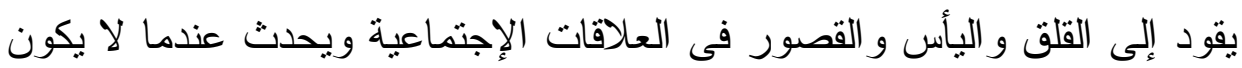



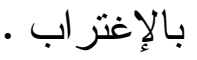




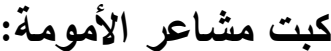

غريزة الأمومة من أقوى الغرائز لدى المر أة فهى تظهر لديها فى الطفولة



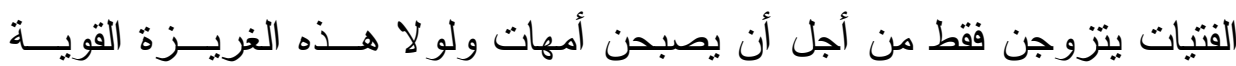

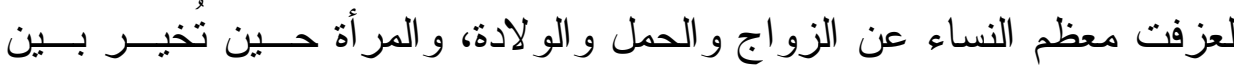

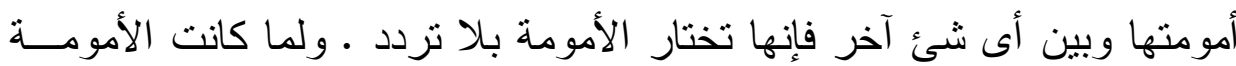

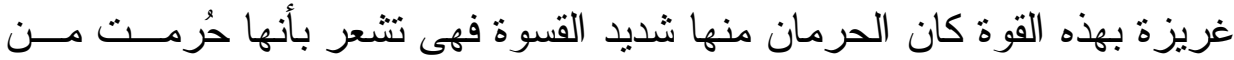

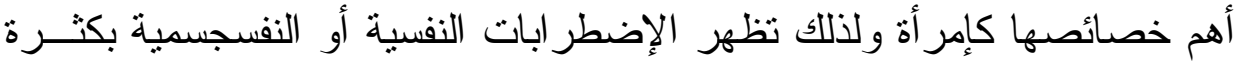

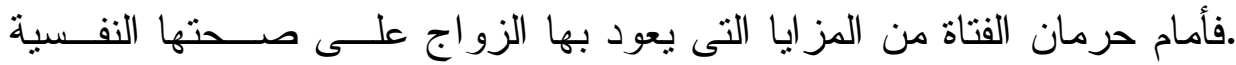
و الجسمية تعيش أزمات نفسية تعوق مسار حياتها وللتخلص من هذه المعاناة تلجأ

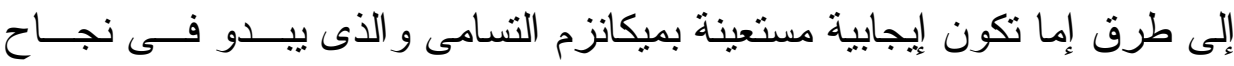

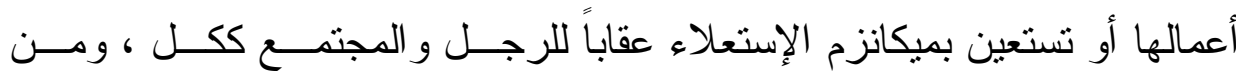


يحقق الحلم بالأمومة عند المر أة و الدليل على ذلك أن الكثير من النساء يفضلّون ندائهم بإسم الإبن فذللك يبعث الثعبور بالسعادة للديهم.



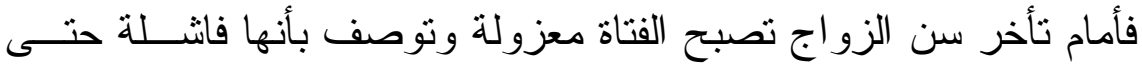

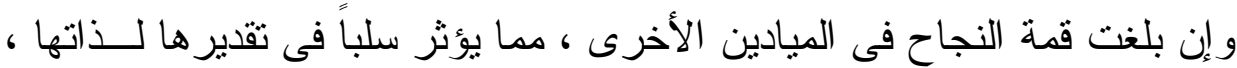

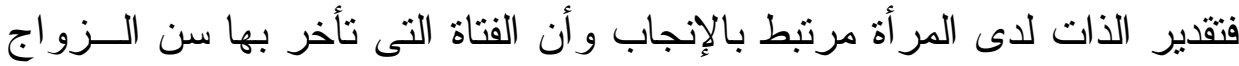

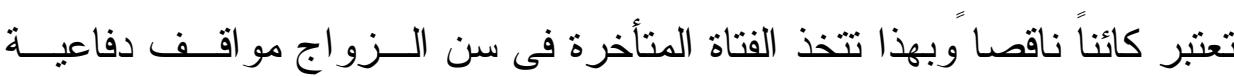
أحياناً تكون عدو انية محاولة لخلق مكانة لها ، فالأحداث الضاغطة التى تعيـشها

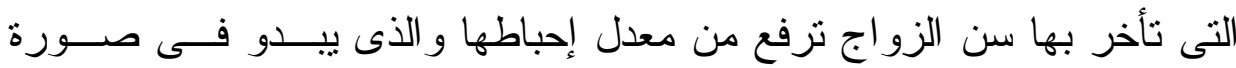


إضطر ابات نفسية كتقدير الذات المنخفض. فالإنفصال عن الإسرة وتكوين أسرة جديدة يُدعم الثُعور بالذات و إثبات الهوية.

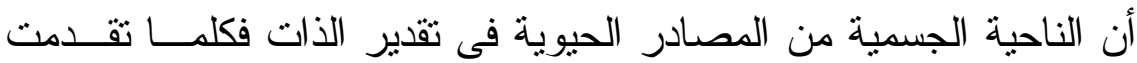

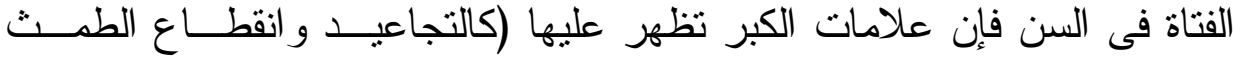

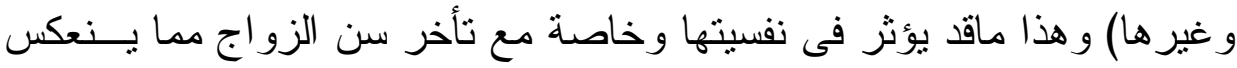

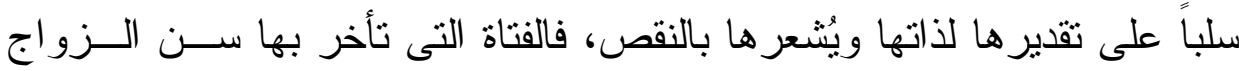

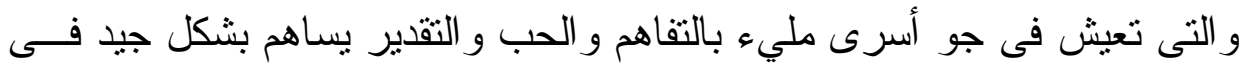

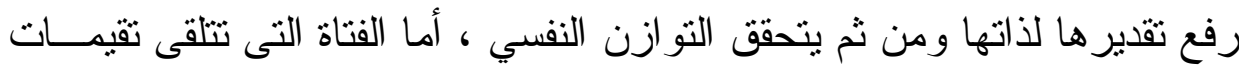

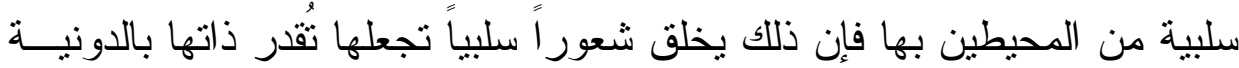

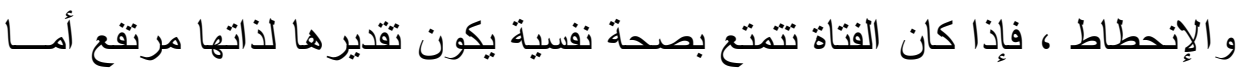

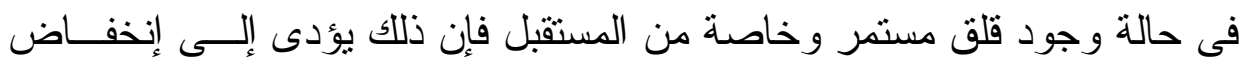
فكرتها عن ذاتها وبالتالى إنخفاض تقدير ها لذاتها.

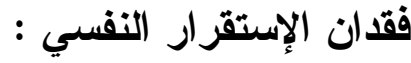

إن الجوع الجنسي جسدى ، ولكن لا يمكن لصاحبه أن يحصل علـى أى

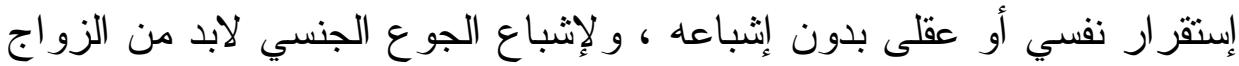

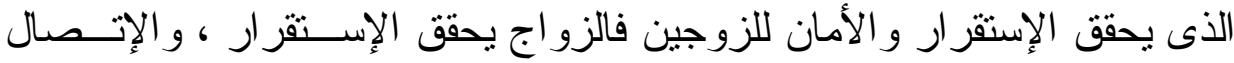

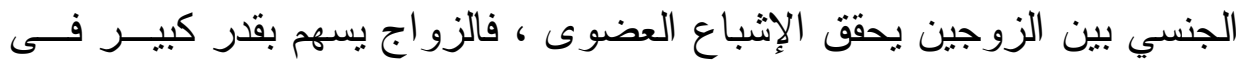

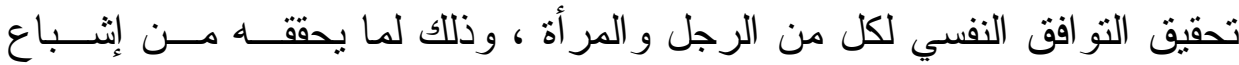
لبعض الحاجات النفسية و الإجتماعية و البيولوجية التى يصعب إثباعها دونــهـ ، و هذا الإثباع يتبعه نوع من الإرتياح النفسي ، ويحد من بعض النوترات النفسية

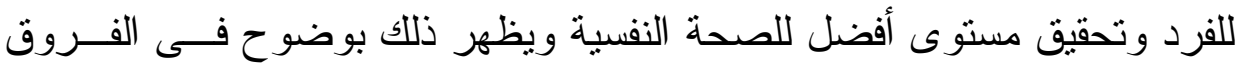
بين المتزوجين و غير المتزوجين. 


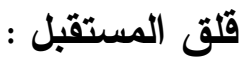

هو خلل أو إضطر اب نفسى المنشأ ينجم عن خبر ات ماضية غير ســارة ، مع تنويه وتحريف إدر اكى معرفى للو اقع وللذات من خلال إستحضار للأذكريات

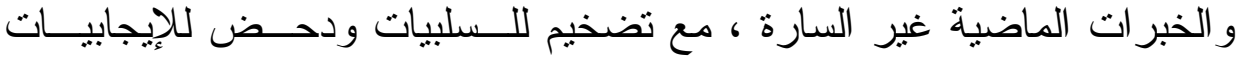

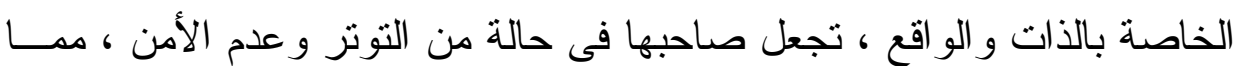

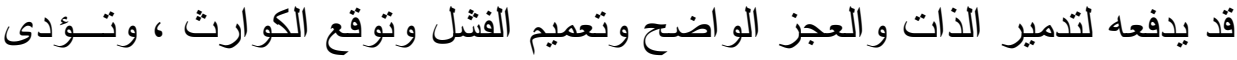

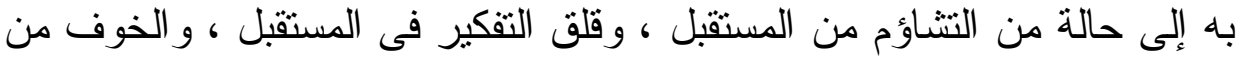

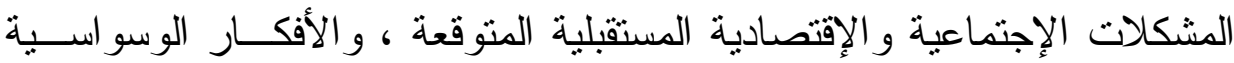

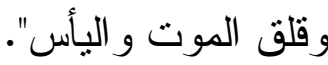

\section{التفسير النفسى لقلق المستقبل :}

يرى أصحاب المنظور الإنساني أن القلق لا ينشأ من ماضي الفرد و انــــا

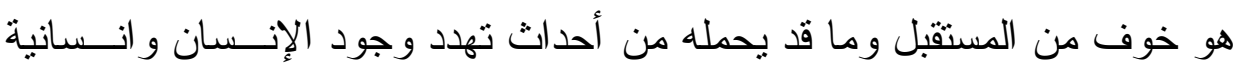
الفرد. فالقلق ينشأ من توقع الفرد من ما قد يحدث ، و الإنسان هو الكائن الحي الوحيد الذي يدرك أن نهايت حتمية و أن الموت قد يحدث في أية لحظة، و بالتالي التيان فإن توقع الموت هو المثير الأساسي للقلق عند الإنسان.

و يؤكد التبار الإنساني على طبيعة الإنسان ككائن خير و متميز لخصائصه الإيجايية، لذا عكف أصحاب هذا التنار على در اسة مشكلات و موضو عات ذات الات التان معنى بالنسبة لوجود الإنسان و رسالت كام ا ردة و حرية الاختيار و المسئولية و





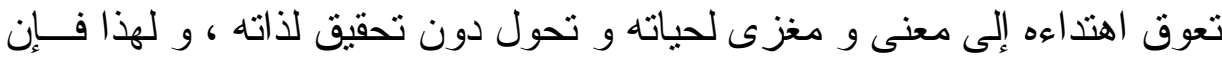


القلق من المنظور الإنساني يرنبط بحاضر الفرد ومستقبل و ليس بأحداث ماضية في حيات كما ذهب إلى ذللك التحليليون السلوكيون.



أن قلق المستقبل يظهر من خلال رؤية أن هنالك مساحة غامضة و مجــال لوجهات نظر سلبية حول ما هو آت في الغد، و هذه المو اقف يمكن أن تسود فـــي

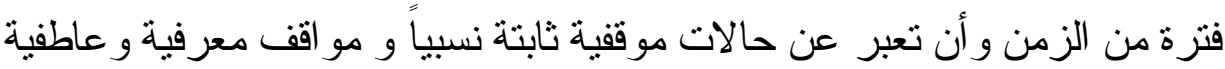

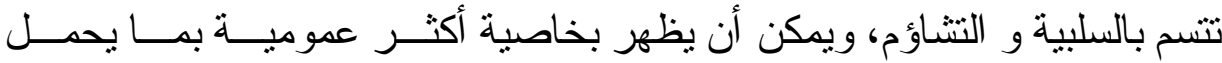

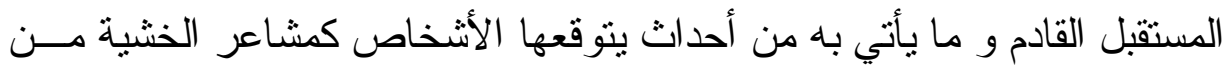

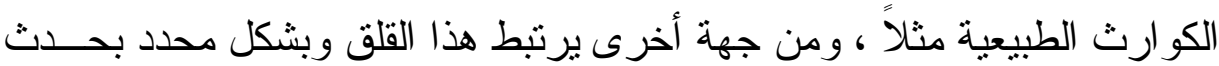

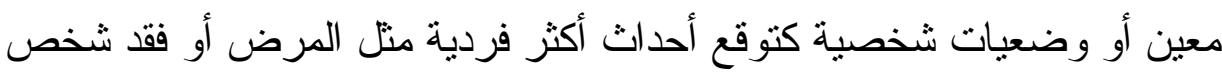

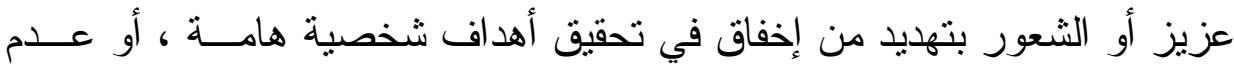


التصرفات او الخطوات الحالية غير مؤكدة كحلول للظروف عير المرغوبة القادمة

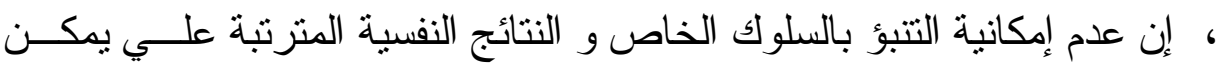

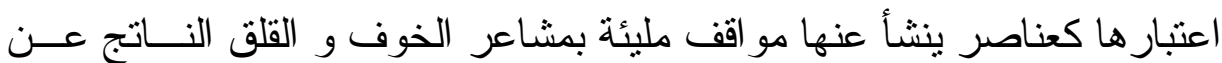

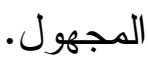



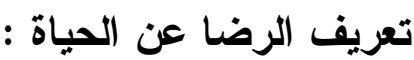

هو تقيم الفرد لنوعية الحياة التي يعيشها طبقا لنسقه القيمي، ويعتمـــ هــــا

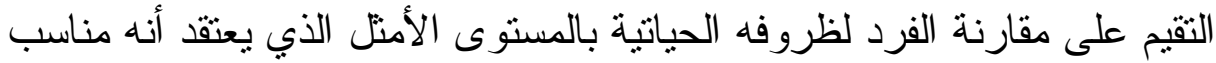
لحياته. 


\section{المفاهيم المرتبطة بالرضاعن الحياة:}

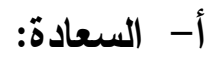

ميز العلماء بين الرضا عن الحياة و السعادة، حيث إن السعادة تعني حالة وجدانية ، بينما الرضا عن الحياة هو عملية تتضمن إصدار حكم معرفي. لئل وبما أن للسعادة مكونين: وهما المكون الاففعالي الوجداني : و الذي يتمنل فـي

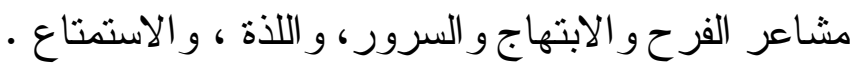
و المكون المعرفي : و الذي يتمثل في الرضـا عن الحياة ، ويعد بمثابـــة التقــــير

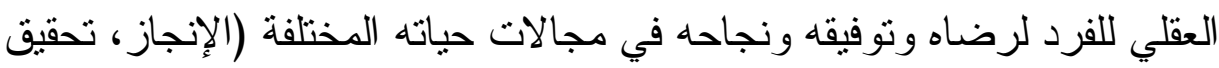



أن يمكن فهم السعادة بكونها إنعكاساً لدرجة الرضا عن الحياة أو إنعكاساً

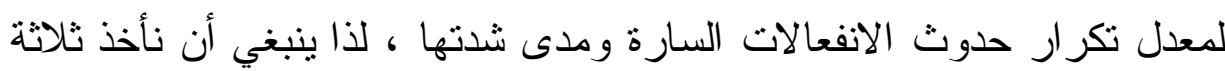
عناصر للسعادة في الاعتبار : الرضا عن الحياة ومجالاته المختلفة. 1- الاستمتاع و الثتعور بالبهجة. r- العناء بما يتضمنه من قلق و اكتئاب.

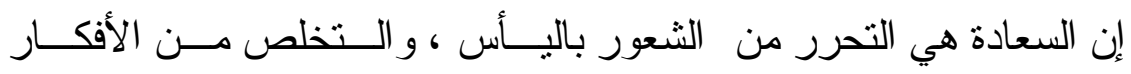

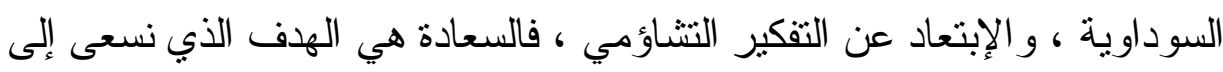

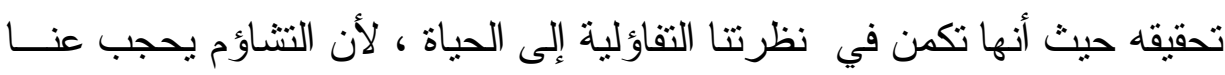

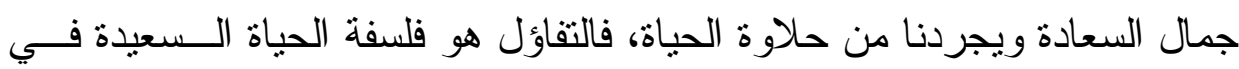
حاضر سعيد ومستقبل مشرق و غد أفضل . 
إن الرضا عن الحياة من أهم مكونات السعادة في الانبا، و على الإنسان أن



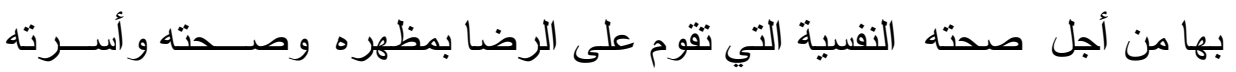



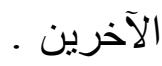

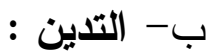

التدين هو الاتجاه الذي يتبناه الفرد ويسلكه ، ويشكل من خلالــهـه مفاهيـــهـ





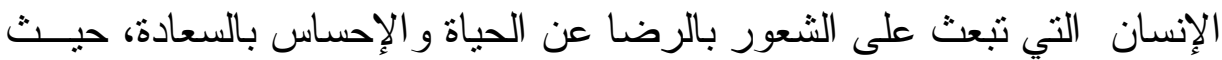

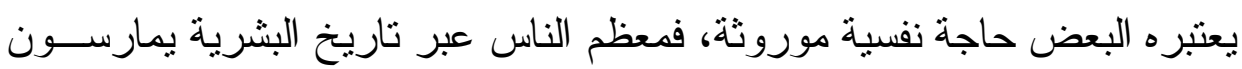

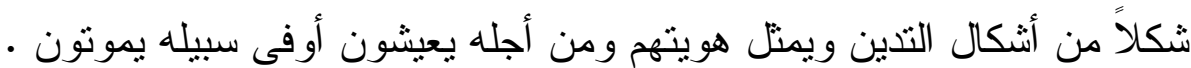
ج-تقبل الحياة: هو مفهوم عام وشامل ويشمل قدرة الفرد على التكيف و التو افق

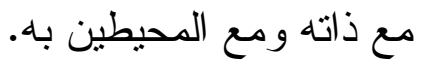

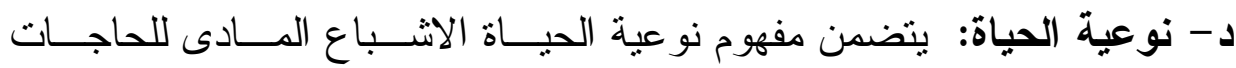

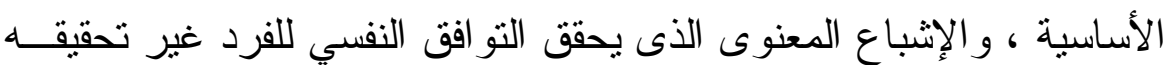


ا. إيمان عبد الحكم البطران (ع ا ـr) : تأخر سن الزواج لاى الثباب" صادر عن الهيئة المصرية العامة للكتاب.

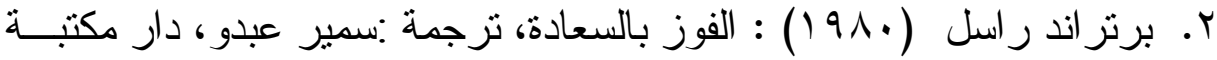



r. دارن شلتز ( (1911 ): نظريات الثخصية ، ترجمة عبد الرحمن القيـسي،

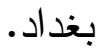

ع. زينب شقير (0 . ب): مقياس قلق المستقبل ، مكتبة النهـضة المـصرية ،

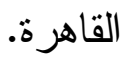

ه. عمر رضا كحالة (9VV ( ) : الزواج ، بيروت ، مؤسسة الرسالة للطباعــة

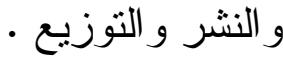

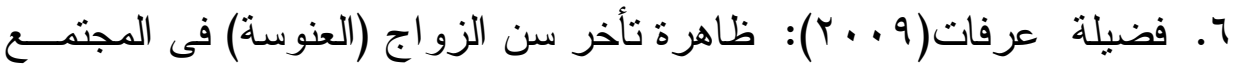
العر اقى، مركز النور للارسات و البحوث.

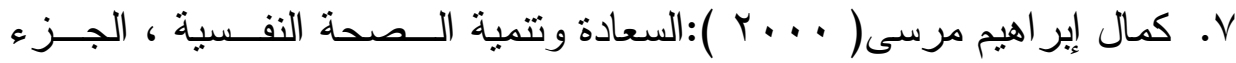

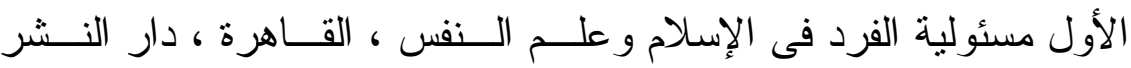
ل اللجامعات





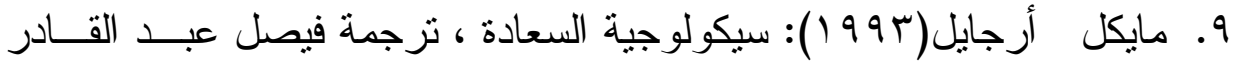
يونس ، العدد IVO ، الكويت ، عالم المعرفة . 


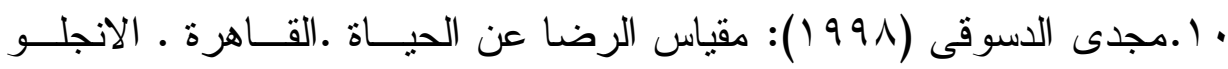

$$
\text { المصرية. }
$$

| (.مصطفى فهمى (9V9 ()): الصحة النفسية ، در اسات فى سيكولوجية التكيف ، طب ، مكتبة الخانكى ، القاهرة..

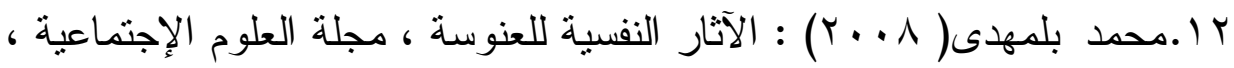
الهيئة الهصرية العامة للكتاب ، العدد (ب) ، العنة 9.

با..محمود الحسن (197V) : الأسرة ومثكلاتها ، طا، دار النهضة العربية ،



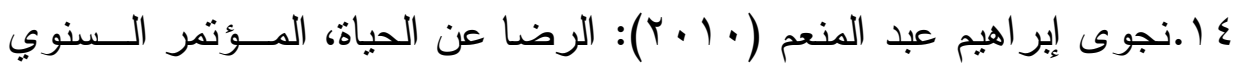

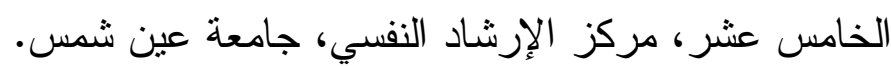

15. Zaleski, Z. (1996). Future Anxiety: Concept Measurement and Preliminary research. Person individual difference. Vol. 21 (2). 